\author{
GIUSEPPE CAMPO $^{1}$ - GAETANA MAZZEO ${ }^{2}$ - SALVATORE NUCIFORA ${ }^{2}$ - GIANCARLO PERROTTA ${ }^{3}$ \\ AGATINO SIDOTI $^{4}$ - SALVATORE BELLA ${ }^{5}$
}

\title{
INSECTS AND FUNGI ON THE RELICT ZELKOVA SICULA (ROSALES, ULMACEAE) IN SICILY (ITALY): NEW RECORDS AND KNOWN SPECIES IN A SHORT REVIEW
}

\footnotetext{
${ }^{1}$ Dip. Reg. dell'Agricoltura, Servizio 4 - Servizio Fitosanitario Regionale e Lotta alla Contraffazione, UO S4.04 Osservatorio per le Malattie delle Piante di Acireale, Via Sclafani, 32/34 - 95024 Acireale (CT), Italy. Ass. Reg. dell'Agricoltura, dello Sviluppo Rurale e della Pesca mediterranea, Viale Regione Siciliana 2771- 90145 Palermo, Italy. E -mail: gcampo@regione.sicilia.it.

${ }_{2}^{2}$ Dipartimento di Agricoltura, Alimentazione e Ambiente, sect. Entomologia applicata. University of Catania, via S. Sofia, 100 - 95123 Catania, Italy. E-mail: gamazzeo@unict.it.

${ }^{3}$ Dip. Reg. dello Sviluppo Rurale e Territoriale, Servizio 15 - Servizio per il Territorio di Siracusa, Via S. Giovanni alle Catacombe, 7 -96100 Siracusa, Italy.E-mail: giancarlo.perrotta@, regione.sicilia.it.

${ }^{4}$ Dip. Reg. dello Sviluppo Rurale e Territoriale, Servizio 4 - Ass. Reg. dell'Agricoltura, dello Sviluppo Rurale e della Pesca mediterranea, Viale Regione Siciliana, 4600 - 90145 Palermo, Italy. E-mail: asidoti@regione.sicilia.it.

${ }^{5}$ Consiglio per la ricerca in agricoltura e l'analisi dell'economia agraria. Centro di ricerca olivicoltura, frutticoltura e agrumicoltura (CREA-OFA) Corso Savoia, 190 - 95024 Acireale (CT), Italy. E-mail: salvatore.bella@crea.gov.it.
}

Campo G., Mazzeo G., Nucifora S., Perrotta G., Sidoti A., Bella S. - Insects and fungi on the relict Zelkova sicula (Rosales, Ulmaceae) in Sicily (Italy): new records and known species in a short review.

The Authors report the results of a study conducted with the purpose of increasing the knowledge about the insects and fungi living on Zelkova sicula Di Pasquale, Garfì \& Quézel, 1992 (Rosales, Ulmaceae). The plant is a very rare relict of the Tertiary period, belonging to a genus of trees extinct in continental Europe. Only two small populations are known living in a restricted woodland in the province of Syracuse, Sicily. The results concern both the insects picked up during surveys that were carried out in 2014 and 2015, and the species of fungi and insects already known on Zelkova sicula from literature. As a result of surveys, two species of Buprestidae, two species of Cerambycidae, and two of Lepidoptera have been recognized. From literature, seven species of phytophagous insects are reported on Zelkova sicula, they belong to Hemiptera: Aphididae (1 sp.), Diaspididae (1 sp.), Coccidae (1 sp.); Coleoptera: Buprestidae (1 sp.), Cerambycidae (2 spp.); and Lepidoptera: Lasiocampidae (1 sp.). Five species of fungi are known from literature and they belong to: Botryosphaeriales (3 spp.), Pleosporales (1 sp.), and Diaporthales (1 sp.).

KEY WorDs: endemic plant, Sicilian Zelkova, insect hosts, tree conservation, phytosanitary status.

\section{INTRODUCTION}

As a consequence of paleogeographic events, Sicily is considered one of the most relevant hotspots of biodiversity in the Mediterranean area (Bella, 2008; Massa et al., 2011; Bella, 2014). The island has about 3,000 species of plants and more than 300 endemic taxa (BRULLo et al., 1995; GIARDINA et al., 2007; DOMINA et al., 2012).

Zelkova (Rosales, Ulmaceae) is a small relict genus that dates back to the Tertiary period. The six extant species are distributed throughout western and eastern Asia (Caucasus: Z. carpinifolia (Pall.) Dippel), East Asia (Z. serrata (Thunb.) Makino) and China (Z. schneideriana HandelMazzetti and Z. sinica C.K. Schneider), except the two in the Mediterranean basin (Sicily: Z. sicula Di Pasq., Garfi \& Quézel and Crete: Z. abelicea (Lam.) Boiss.) (GTC, 2017). Habitat loss, logging, increased periods of drought, and limited reproduction represent major threats for these species. The IUCN list evaluates this species as 'Critically Endangered' (KozlowsKi \& GRATZFELD, 2013). Some species are threatened with extinction and others are still waiting assessment, so a global action plan 'Project Zelkova' has been developed (FINESCHI et al., 2004; GARFì \& BUORD, 2012).
The arthropod fauna living on the Sicilian endemic Zelkova sicula have been rarely studied, and only little data are currently available (CAMPO et al., 2015), whereas fungal flora was studied in the past years and the results have been already published (GRANATA et al., 2002; Sidoti \& GrANATA, 2005; TORTA et al., 2008; SiDOTI et al., 2016).

The aim of this study is to improve the knowledge both of the entomofauna and the fungal flora associated with this rare species and to group the currently known data on the phytosanitary issues that affect this plant.

\section{MATERIALS AND METHOD}

\section{THE STUDY SITES}

Samples were collected in the Iblei Mountains in southeastern Sicily, in the province of Syracuse (Fig. I):

- site ZS1: Buccheri, bosco Pisano, 450-550 m a.s.1., $37^{\circ} 10^{\prime} 18^{\prime \prime} \mathrm{N}-14^{\circ} 51^{\prime} 37^{\prime \prime}$ E (SIC: ITA 090022 "Bosco Pisano" - Buccheri, Francofonte and Vizzini, 1850,82 ha);

- site ZS2: Melilli, contrada Ciranna, 310-350 m a.s.1., $37^{\circ} 12^{\prime} 40^{\prime \prime} \mathrm{N}-15^{\circ} 02^{\prime} 41^{\prime \prime} \mathrm{E}$ (SIC: ITA 090024 "Cozzo Ogliastri" - Melilli, 1338,16 ha). 


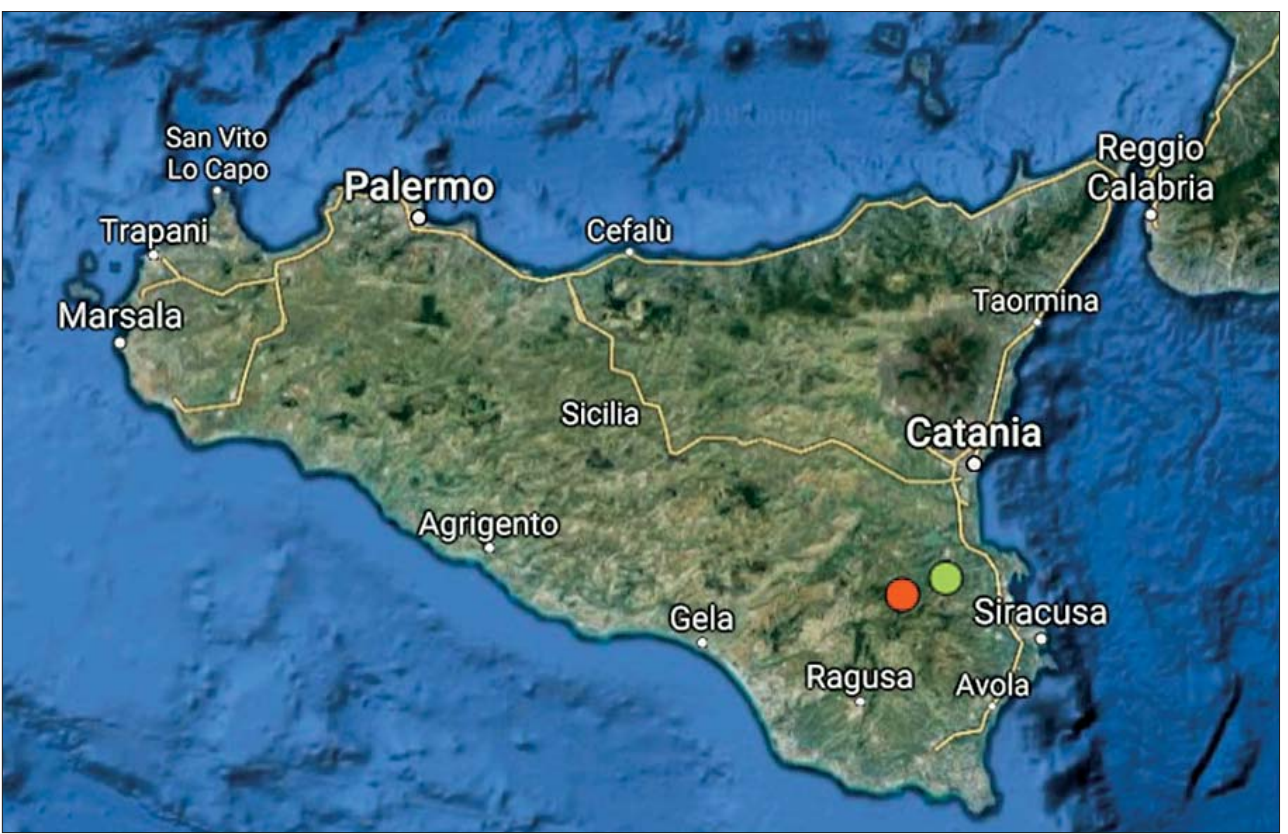

Fig. I - Presence of Zelkova sicula in southeastern Sicily (Iblei Mts.): sites ZS1 (red), and ZS2 (green).

\section{THE PLANT}

Endemic to Sicily, Zelkova sicula is considered one of the rarest and most endangered trees worldwide. It is a deciduous shrub or tree usually 2-3 m high. It was first discovered in 1991 on the northern slopes of the Iblei Mountains in southeastern Sicily, near the municipality of Buccheri, and was thought to exist only as a single population of 230 individuals over an area of 0.4 ha (DI PASQUALE et al., 1992). A second population was discovered in the same mountain range in 2009 , near the municipality of Melilli, and only includ 1,200 individuals covering an area of $0.8 \mathrm{ha}$. The two populations are $17 \mathrm{~km}$ apart (GTC, 2017). This species has anomalous pollen, which may explain why all seeds appear to be sterile; propagation is from root suckers. Studies have indicated that the remaining populations of Zelkova sicula may be traced to just one individual. This lack of genetic variation reduces the ability of the species to face environmental and/or biological changes (GARFì \& BUORD, 2012). This species has been classified as "Critically Endangered" by the IUCN Red List because the areas in which it is found are very small, and both the areas and the number of individuals seem to be continuing to decline (MONTMOLLIN \& STRAHM, 2005). Zelkova sicula has been the object of a conservation project since 2011 (LIFE10NAT/IT/000237).

SAMPLING METHODS AND SUMMARY

OF THE BIBLIOGRAPHIC DATA

Field surveys were carried out in the years 2014-2015, in the spring-summer every 15 days. In both sites where Zelkova sicula grows, direct observations were made on plants for collecting phythophagous insects, meanwhile dead or suffering wooden samples were picked up for the possible presence of saproxylophagous insects. Samples, consisting of portions of green or woody organs, were taken, placed in containers and carried to the laboratory. Wood insects and phyllophagous species, were isolated in cages with standard temperature and relative humidity ( 25 ${ }^{\circ} \mathrm{C}$ and $65 \% \mathrm{RH}$ ), and regularly inspected for collecting adults. In the case of phytomize species, they were observed at binoculars and prepared on a slide for species identification. Beetles have been prepared dry and identified by using dichotomous keys or by resorting to specialists.
Bibliographical search has been conducted on insects and fungi found on Zelkova sicula from its discovery to date in order to draw up the list of species already known.

\section{ACRONYMS AND ABBREVIATIONS USED IN THE TEXT}

IUCN: International Union for Conservation of Nature

SIC: site of community importance

ZS: Zelkova sicula

leg.: legit

loc.: locality

coll.: collected

emer: emerged

ex./exx.: specimen/specimens

The following data are given for each species: chorotype, larval host plants, and data of collection. The systematics and nomenclature follow SAMA (2013) with the recent updates by BAVIERA et al. (2017) for the Cerambycidae family and KUBAN \& BílÝ (2013) for the Buprestidae family. The rapid evolution of the taxonomy of fungi has led us to refer exclusively to the classification reported by the 'Index fungorum bioscience database' (CABI, 2017). The specimens of insects studied are stored in the collection to the UO S4.04 - Osservatorio per le Malattie delle Piante di Acireale.

\section{RESULTS}

NEW RECORDED TAXA

\section{COLEOPTERA}

Family BUPRESTIDAE Leach, 1815

Polycestinae Lacordaire, 1857

Acmaeoderini Kerremans, 1893

Acmaeoderella (Omphalothorax) adspersula adspersula (Illiger, 1803)

\section{CHOROTYPE: Olomediterranean.}

Material eXamined: Buccheri, loc. Bosco Pisano, 1 ex., coll. 27.V.2015, emer. 2016. Melilli, loc. Ciranna, 1 ex., coll. 14.V.2014, emer. 2015. 
LARVAL HOST PLANTS: Aceraceae (Acer), Anacardiaceae (Pistacia, Rhus), Celtidaceae (Celtis), Cesalpinaceae (Ceratonia), Cistaceae (Cistus), Fabaceae (Acacia, Cytisus, Genista, Retama, Spartium), Fagaceae (Castanea, Quercus), Ephedraceae (Ephedra), Euphorbiaceae (Euphorbia), Moraceae (Ficus), Rosaceae (Malus, Sorbus), Salicaceae (Populus), Thymelaeaceae (Thymelaea), Ulmaceae (Ulmus), Vitaceae (Vitis), Zygophyllaceae (Zygophyllum) (CURLetTi, 1994; Mifsud \& BarTHer, 2005).

REMARKS: the larvae feed on wood of several plants and the adults are anthophilous (Luna, 2013; Ceccolini et al., 2014).

\section{Buprestinae Lacordaire, 1857 \\ Anthaxiini Gory \& Laporte, 1839 \\ Anthaxia (Haplanthaxia) umbellatarum umbellatarum} (Fabricius, 1787)

CHOROTYPE: Euro-Mediterranean.

Material examined: Melilli, loc. Ciranna, 1 ex., coll. 14.V.2014, emer. 2015; 1 ex., coll. 5.VIII.2014, emer. 2015; 5 exx., coll. 09.VII.2015, emer. 2016; 6 exx., coll. 25.IX.2015, emer. 2016.

Larval host Plants: Anacardiaceae (Pistacia), Cesalpinaceae (Cercis, Ceratonia), Cupressaceae (Cupressus), Fabaceae (Acacia, Cytisus), Fagaceae (Castanea, Quercus), Moraceae (Ficus), Rosaceae (Cydonia, Prunus, Pyrus, Rosa), Salicaceae (Salix), Ulmaceae (Ulmus) (Curletti, 1994).

REMARKS: the larvae of this polyphagous species feed both on deciduous plants and conifers, unlike the majority of Buprestidae (Curletti, 1981). The adults are anthophilous (Luna, 2013).

Family CERAMBYCIDAE Latreille, 1802

Cerambycinae Latreille, 1802

Graciliini Mulsant, 1839

Penichroa fasciata Dejean, 1839

Chorotype: Turanic-European.

Material exAmined: Melilli, loc. Ciranna, 2 exx., coll. 5.VIII.2014, emer. 2015; 16 exx., coll. 09.VII.2015, emer. 2016; 12 exx. 14.V.2014, emer. 2015.

LaRval host Plants: Anacardiaceae (Pistacia), Cesalpinaceae (Ceratonia, Cercis, Cytisus), Cupressaceae (Thuya), Fabaceae (Glycyrrhiza), Fagaceae (Fagus, Quercus), Moraceae (Ficus, Morus), Myrtaceae (Eucalyptus), Pinaceae (Pinus), Rosaceae (Prunus) (BAVIERA et al., 2017).

REMARKS: this species is extremely polyphagous mostly feeding on deciduous trees, sometimes on conifers (Sama et al., 2010).

\section{Gracilia minuta (Fabricius, 1781)}

Chorotype: Cosmopolitan.

MATERial EXAmined: 24 exx., coll. 27.V.2015, emer. 2016; 18 exx., coll. 09.VII.2015, emer. 2016; 6 exx., coll. 25.IX.2015, emer. 2016.
LARVAL HOST PlanTS: Aceraceae (Acer), Anacardiaceae (Pistacia), Betulaceae (Betula), Celastraceae (Euonymus), Cesalpinaceae (Ceratonia), Corylaceae (Corylus), Fagaceae (Castanea, Quercus), Hippocastanaceae (Aesculus), Juglandaceae (Juglans), Moraceae (Ficus), Pinaceae (Cedrus, Pinus), Rhamnaceae (Rhamnus), Rosaceae (Crataegus, Malus, Prunus, Rosa, Rubus, Sorbus), Rutaceae (Citrus), Salicaceae (Salix), Ulmaceae (Ulmus) (BAVIERA et al., 2017).

REMARKS: this species affects thin twigs of deciduous trees and shrubs. Adults are xylophagous (Contarini, 2014).

\section{LEPIDOPTERA}

Family SATURNIIDAE Boisduval, 1837

Saturniinae Boisduval, 1837

Saturniini Boisduval, 1837

Saturnia (Eudia) pavoniella (Scopoli, 1763)

Chorotype: European.

Material eXAmined: Buccheri, loc. Bosco Pisano, 1 ex., VI.2004.

LARVAL HOST PLANTS: Betulaceae (Carpinus), Elaeagnaceae (Hippophae), Fagaceae (Quercus), Betulaceae (Betula), Salicaceae (Salix), Ericaceae (Calluna, Erica, Spiraea, Vaccinium), Lythraceae (Lythrum), Rosaceae (Crataegus, Filipendula, Potentilla, Prunus, Pyrus, Rosa, Rubus) (Mazzei et al., 2017).

REMARKS: young larvae generally feed on low vegetation and, after a period in which gather, they disperse and larger larvae tend to be found higher up on shrubs (Pittaway, 2018).

\section{Family NYMPHALIDAE}

Nymphalinae Swainson (1927)

Nymphalis polychloros (Linnaeus, 1758)

Chorotype: Centralasiatic-Euro-Mediterranean.

Material eXAmined: Buccheri, loc. Bosco Pisano, 1 ex., VI.2004.

LARVAl host Plants: Salicaceae (Salix), Rosaceae (Crataegus, Prunus, Malus, Pyrus, Sorbus), Salicaceae (Populus), Ulmaceae (Ulmus) (Mazzei et al., 2017).

REMARKS: this species, that is widespread in Europe, overwinters as adults which fly from March to April and are most active in summertime (Jurc et al., 2016).

\section{TAXA PREVIOUSLY REPORTED ON ZELKOVA SICULA}

Hemiptera, Aphididae Zelkovaphis trinacriae Barbagallo, 2002

This Eriosomatine aphid lives exclusively on Zelkova sicula protected inside 'clustering type galls' (BARBAGALLO, 2002). The aphid likely performs a dioic lifecycle, with adults from mid-April to early summer, whose secondary host plant remains yet unknown (BARBAGALLO \& COCUZZA, 2008). 
REMARKS: the aphid has been found in both stations, but is present with a more abundant population in the ZS1 site.

\section{Hemiptera, Coccidae}

\section{Parthenolecanium sp.}

Some mature females have been recorded on the twigs of $Z$. sicula in the ZS1 site. The features of these females, characterized by a brown to reddish colour and convex body, seemed to lead to the genus Parthenolecanium.

REMARKS: further investigation are needed for the correct identification of the species (MAZZEO et al., 2016).

\section{Hemiptera, Diaspididae \\ Aspidiotus nerii Bouché, 1833}

The oleander scale, a cosmopolitan species, is highly polyphagous, living on 325 genera in 120 families host plants. It is considered a pest of crops and ornamental plants (García Morales et al., 2016).

REMARKS: the specimens, mostly females, were found in the ZS1 site, on the lower surface of leaves, where the presence of hairs caused a modification of the scale covers that showed an irregular outline (MAZZEO et al., 2016).

\section{Coleoptera, Buprestidae \\ Acmaeodera (Acmaeodera) pilosellae pilosellae} (Bonelli, 1812)

LARVAL hOST PLANTS: Aceraceae (Acer), Anacardiaceae (Pistacia), Corylaceae (Corylus), Fabaceae (Colutea), Fagaceae (Quercus), Juglandaceae (Juglans), Rosaceae (Amygdalus, Crataegus, Prunus) (Curletti, 1994).

REMARKS: this species was only found in the ZS1 site (LONGO \& CAMPO, 2004).

\section{Coleoptera, Cerambycidae \\ Chlorophorus (Perderomaculatus) sartor (Müller, 1766)}

Larval host plants: Anacardiaceae (Pistacia), Cesalpinaceae (Ceratonia, Gleditsia), Fabaceae (Cytisus, Robinia), Fagaceae (Castanea, Fagus, Quercus), Corylaceae (Ostrya), Moraceae (Ficus), Rhamnaceae (Paliurus), Rosaceae (Crataegus), Salicaceae (Salix), Ulmaceae (Ulmus) (BAVIERA et al., 2017).

REMARKS: this species was found in the ZS2 site (SIDOTI et al., 2016).

\section{Niphona picticornis (Mulsant, 1839)}

LARVAl host Plants: Anacardiaceae (Pistacia), Arecaceae (Phoenix), Caprifoliaceae (Sambucus), Cesalpinaceae (Cercis), Euphorbiaceae (Euphorbia), Fabaceae (Calycotome, Genista, Robinia, Spartium), Fagaceae (Castanea, Quercus), Lauraceae (Laurus), Moraceae (Ficus, Morus), Pinaceae (Pinus), Punicaceae (Punica), Rhamnaceae (Rhamnus), Rosaceae (Prunus), Ulmaceae (Ulmus) (BAVIERA et al., 2017).

REMARKS: this cerambyx has been found in both stations ZS1 and ZS2 (SIDOTI et al., 2016).

\section{Lepidoptera, Lasiocampidae Lasiocampa (Lasiocampa) quercus sicula} (Staudinger, 1861)

Larval host plants: Betulaceae (Alnus, Betula), Caprifoliaceae (Lonicera), Salicaceae (Populus, Salix), Grossulariaceae (Ribes), Rosaceae (Rubus, Spiraea, Malus, Sorbus, Prunus), Fabaceae (Trifolium), Ericaceae (Andromeda, Calluna, Ledum, Vaccinium), Oleaceae (Syringa), Pinaceae (Larix) (Mazzei et al., 2017).

REMARKS: generically reported as Lasiocampide sp. by LONGO \& CAMPO (2004) in the ZS1 site.

FUNGI

\section{Botryosphaeriales, Botryosphaeriaceae Botryosphaeria sarmentorum \\ A.J.L. Phillips, Alves \& Luque, 2005}

Anamorph: Dothiorella sarmentorum (Fr.) Phillips, Alves \& Luque, 2005 (=Diplodia sarmentorum (Fr.) Fries).

Botryosphaeria sarmentorum is common in Europe, where it is found in its anamorphic state on a wide range of woody hosts. It is not known if this species is pathogenic, but it is most likely a saprophyte because it is often seen associated with pathogens (PHILLIPS, 2017).

REMARKS: cankers on the bark of twigs and stems and necrotic woody tissues (pycnidia) in the ZS1 site (GRANATA et al., 2002; SidOTI \& GRANATA, 2005; TORTA et al., 2008).

\section{Botryosphaeria iberica}

A.J.L. Phillips, Luque \& Alves, 2005

Anamorph: Dothiorella iberica A.J.L. Phillips, Luque \& Alves, 2005.

This species is similar to $B$. sarmentorum. It is reported associated with the formation of canker on trunks and branches of Malus sp., Quercus sp., Persea americana Mill., Vitis vinifera L., and almond (PHILLIPS et al., 2005; ESKALEN \& MCDONALD, 2011; PITT et al., 2008; Doll et al., 2015).

REMARKS: cankers on the bark of twigs and stems, and necrotic woody organs (pycnidia) in the ZS2 site (SIDOTI et al., 2016)

\section{Neofusicoccum ribis (Slippers, Crous \& M.J. Wingf.) Crous, Slippers \& A.J.L. Phillips, 2006 (=Fusicoccum aesculi Corda, 1829)}

Taxonomic reviews have given rise to Neofusicoccum gen. nov., in which were included Fusicoccum and Diplodia like synanamorphs as F. aesculi (CROUS et al., 2006). More than 250 hosts are listed in FARR \& ROSSMAN (2016) but many of the reports were published before the concept of $N$. ribis was clarified by SLIPPERS et al. (2004) and are thus not reliable. $N$. ribis was identified as the main cause of leaf blight disease in Hevea brasiliensis (Willd. ex A. Juss.) Müll. Arg. in commercial plantations in Malaysia (NGOBISA et al., 2013).

REMARKS: cankers on the bark of twigs and stems and necrotic woody tissues (pycnidia) in the ZS1 site (GRANATA et al., 2002; SIDOTI \& GRANATA, 2005; TORTA et al., 2008). 
Pleosporales, Didymosphaeriaceae

Didymosphaeria variabile (Riccioni, Damm, Verkley \& Crous) Ariyawansa \& K.D. Hyde, 2014

(= Paraconiothyrium variabile Riccioni, Damm, Verkley \& Crous, 2008)

The Didymosphaeriaceae (= Montagnulaceae) family includes saprobes, endophytes, and pathogens associated with a wide variety of substrates worldwide (ARIYAWANSA et al., 2014). D. variabile (Paraconiothyrium variabile) has been isolated from discoloured tissues of various decaying woody host plants such as Prunus persica L., P. salicina Lindl. and Malus sp. in South Africa; Actinidia chinensis Planch. and A. deliciosa (A. Chev.) C.F. Liang \& A.R. Ferguson in Italy; Laurus nobilis L. in Turkey (DAMM et al., 2008; Cloete et al., 2011). Ligoxigakis et al. (2013) reported severe leaf spot on Phoenix theophrasti Greuter caused by $P$. variabile in Greece. This species is also endophytic, and laboratory research focused on secondary metabolites produced by endophytic fungi showed that, when co-cultured with $F$. oxysporum, it had an antagonistic effect on the growth of the phytopathogen and actively suppressed the production of beauvericin, a mycotoxin of $F$. oxysporum involved in virulence (PRADO et al., 2015).

REMARKS: cankers on the bark of twigs and stem, and necrotic woody organs (pycnidia) in the ZS2 site (SIDOTI et al., 2016).

Diaporthales, Diaporthaceae

Diaporthe neotheicola A.J.L. Phillips \& J.M. Santos, 2009

Anamorph: Phomopsis theicola Curzi 1927.

Diaporthe neotheicola has been reported as an agent of shoot blight and cankers and branch dieback on many cultivated plants such as Diospyros kaki L. (Golzar et al., 2012), Olea europaea L. (Frisullo et al., 2015), Actinidia deliciosa (Thomidis et al., 2013) and Vitis vinifera (KALITERna et al., 2012). UdAYANGA et al. (2014) recently reviewed the taxonomy, based on molecular studies, of some species of the genus Diaporthe and considered $D$. neotheicola a synonym of Diaporthe foeniculina (Sacc.), basionym Phoma foeniculina Sacc., which includes a wider range of hosts and present in Argentina, USA (California), Europe (Portugal, Spain, Italy and Greece), South Africa, Australia and New Zealand.

REMARKS: cankers on bark of twigs and stems, and necrotic woody organs (pycnidia) in the ZS2 site (SIDOTI et al., 2016).

The results of field surveys and bibliographical search are summarized in Table 1.

\section{CONCLUDING REMARKS}

The relationship between insects and their host plants are very interesting, especially if the plants are endemic and relict and confined to a restricted area (BELLA et al., 2006; BELLA \& RAPISARDA, 2014). Zelkova sicula, in particular, have to be accurately monitored, due to its reproductive biology, the small number of living individuals and the severe environment where it grows, in order to avoid infestations by insects or diseases that could kill the plants (GARFÌ \& BUORD, 2012; CAMPO et al., 2015). The species we recorded in our surveys are apparently not harmful to Zelkova plants, but some of the insects collected are known

Table 1 - List of the newly recorded and known insects and fungi species reported on Zelkova sicula in Sicily.

\begin{tabular}{|c|c|c|c|}
\hline ORDER & FAMILY & TAXON & REFERENCES \\
\hline \multicolumn{4}{|c|}{ Insects } \\
\hline \multirow{3}{*}{ HEMIPTERA } & APHIDIDAE & Zelkovaphis trinacriae Barbagallo, 2002 & $\begin{array}{c}\text { Barbagallo, 2002; Barbagallo \& Cocuzza, } \\
2008\end{array}$ \\
\hline & COCCIDAE & Parthenolecanium sp. & Mazzeo et al., 2016 \\
\hline & DIASPIDIDAE & Aspidiotus nerii Bouché, 1833 & Mazzeo et al., 2016 \\
\hline \multirow{7}{*}{ COLEOPTERA } & \multirow{3}{*}{ BUPRESTIDAE } & $\begin{array}{l}\text { Acmaeodera (Acmaeodera) pilosellae pilosellae (Bonelli, } \\
1812 \text { ) }\end{array}$ & Longo \& Campo, 2004 \\
\hline & & 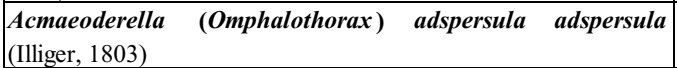 & New record \\
\hline & & $\begin{array}{ll}\begin{array}{l}\text { Anthaxia (Haplanthaxia) } \\
\text { (Fabricius, 1787) }\end{array} & \text { umbellatarum umbellatarum } \\
\end{array}$ & New record \\
\hline & \multirow{4}{*}{ CERAMBYCIDAE } & Penichroa fasciata Dejean, 1839 & New record \\
\hline & & Gracilia minuta (Fabricius, 1781) & New record \\
\hline & & Chlorophorus (Perderomaculatus) sartor (Müller, 1766) & Sidoti et al., 2016 \\
\hline & & Niphona picticornis (Mulsant, 1839) & Sidoti et al., 2016 \\
\hline \multirow{3}{*}{ LEPIDOPTERA } & LASIOCAMPIDAE & Lasiocampa (Lasiocampa) quercus sicula (Staudinger, 1861) & Longo \& Campo, 2004 \\
\hline & SATURNIIDAE & Saturnia (Eudia) pavoniella (Scopoli, 1763) & New record \\
\hline & NYMPHALIDAE & Nymphalis polychloros (Linnaeus, 1758) & New record \\
\hline \multicolumn{4}{|c|}{ Fungi } \\
\hline \multirow{3}{*}{ BOTRYOSPHAERIALES } & \multirow{3}{*}{ BOTRYOSPHAERIACEAE } & $\begin{array}{l}\text { Botryosphaeria sarmentorum A.J.L. Phillips, Alves \& Luque, } \\
2005\end{array}$ & $\begin{array}{c}\text { Granata et al. , 2002; Sidoti \& Granata, } \\
\text { 2005; Torta et al., } 2008\end{array}$ \\
\hline & & Botryosphaeria iberica A.J.L. Phillips, Luque \& Alves, 2005 & Sidoti et al., 2016 \\
\hline & & $\begin{array}{l}\text { Neofusicoccum ribis (Slippers, Crous \& M.J. Wingf.) Crous, } \\
\text { Slippers \& A.J.L. Phillips, } 2006\end{array}$ & $\begin{array}{l}\text { Granata et al. , 2002; Sidoti \& Granata, } \\
\text { 2005; Torta et al., } 2008\end{array}$ \\
\hline PLEOSPORALES & DIDYMOSPHAERIACEAE & $\begin{array}{l}\text { Didymosphaeria variabile (Riccioni, Damm, Verkley \& Crous) } \\
\text { Ariyawansa \& K.D. Hyde, } 2014\end{array}$ & Sidoti et al., 2016 \\
\hline DIAPORTHALES & DIAPORTHACEAE & Diaporthe neotheicola A.J.L. Phillips \& J.M. Santos, 2009 & Sidoti et al., 2016 \\
\hline
\end{tabular}


to be harmful, e.g. Parthenolecanium species or Aspidiotus nerii that are pests of cultivated trees and ornamentals.

Fungal species, that are agents of cankers on the bark of twigs and stems and on necrotic woody tissues are common. The Botryosphaeriaceae comprises endophytes, saprobes, and plant pathogens. Some taxa in Botryosphaeriaceae have recently undergone nomenclatural changes (DISSANAYAKE et al., 2016). Botryosphaeria is a species-rich genus with a cosmopolitan distribution commonly associated with dieback and cankers of woody plants. Diaporthe species and their Phomopsis anamorphs are endophytes and pathogens on a wide range of plant hosts and are responsible for several diseases, some of which are of economic importance (UDAYANGA et al., 2014).

The highly degraded ecological environment in which Zelkova sicula has long developed has undoubtedly represented the determining factor in the state of suffering of the population. In addition, the summer climatic conditions, often characterized by high temperatures and especially low rainfall, cause frequent leaf drop in the warmer months, a phenomenon now contained by rescue irrigation in ZS1. Plants in this weakened state are more prone to attack by fungal species and insects (CRIST \& SHÖENEWEISS, 1975; LONGO \& CAMPO, 2002; BELLA, 2013). Fungal species living in the plant in a latent endophytic state become under stress conditions favouring the decline of the population.

Our investigation and bibliographic data collection summarise the insect pest status and health issues related to this rare Sicilian tree, and other studies are still ongoing to increase knowledge in various fields for this interesting endemic species, especially, i.e. on the symbiotic relationships between insect and fungi.

\section{ACKNOWLEDGMENTS}

Studies were supported by Zelkov@zione 'Azioni urgenti per salvare Zelkova sicula dall'estinzione' project - Azione E.3, aimed at protecting the Sicilian endemic species Zelkova sicula, funded by the Regione Siciliana Assessorato Regionale del Territorio e dell'Ambiente Dipartimento regionale dell'Ambiente (LIFE10NAT/IT/ 000237)

The authors are grateful to "Servizio per il Territorio" of Syracuse, and the local Distaccamento Forestale of Buccheri (Syracuse) for the collaboration, and to Dr. Ignazio Sparacio (Palermo) for the help given for the identification of Anthaxia umbellatarum.

\section{REFERENCES}

Ariyawansa H.A, Tanaka K., Thambugala K.M., Phookamsak R., Tian Q., Camporesi E., Hongsanan S., Monkai J., Wanasinghe D.N., Mapook A., Chukeatirote E., Kang J.C., Xu J.C., McKenzie E.H.C., Jones E.B.G., Hyde K.D., 2014 - A molecular phylogenetic reappraisal of the Didymosphaeriaceae (= Montagnulaceae). - Fungal Diversity, 68: 69-104.

BARBAGALLO S., 2002 - Zelkovaphis trinacriae, a new Eriosomatine aphid genus and species living on Zelkova in Sicily (Rhynchota: Aphididae). - Bollettino di Zoologia Agraria e di Bachicoltura, Ser. II, 34 (3): 281-301.

Barbagallo S., Cocuzza G., 2008 - Annotazioni bioecologiche su Zelkovaphis trinacriae afide galligeno (Insecta Hemiptera) della Zelkova sicula (Ulmaceae). Naturalista siciliano, S. IV, XXXII (3-4), 455-470.
Baviera C., Bellavista M., Altadonna G., Turrisi G.F., Bella S., Muscarella C., Sparacio I., 2017 - The Cerambycidae (Coleoptera: Chrysomeloidea) of Sicily: recent records and updated checklist. - Atti della Accademia Peloritana dei Pericolanti. Classe di Scienze Fisiche, Matematiche e Naturali, 95 (1), A2: 1-79.

Bella S., 2008 - Caryocolum siculum sp. n. (Gelechiidae), feeding on Gypsophila (Caryophyllaceae) in Sicily. - Nota lepidopterologica, 31 (1): 69-75.

Bella S., 2013 - New alien insect pests to Portugal on urban ornamental plants and additional data on recently introduced species. - Annales de la Société entomologique de France (N.S.), 49 (4): 374-382.

BELLA S., 2014 - Invasive insect pests and their associated parasitoids on ornamental urban plants on Corfu island Phytoliriomyza jacarandae Steyskal and Spencer 1978 (Diptera, Agromyzidae) a new record in Greece. Hellenic Plant Protection Journal, 7: 53-59.

Bella C., Bella S., Turrisi R.E., Turrisi G.F., $2006-L a$ biodiversità della valle del fiume Vizzini (Sicilia, Iblei) e le azioni per la sua tutela. - Atti del Forum delle Associazioni Ambientaliste della Provincia di Catania, Catania 22 maggio 2004: 169-180. Nuova Zangara Stampa Editrice.

Bella S., RAPISARDA C., 2014 - New findings in Italy of the recently introduced alien psyllid Macrohomotoma gladiata and additional distributional records of Acizzia jamatonica and Cacopsylla fulguralis (Hemiptera Psylloidea). - Redia, XCVII: 151-155.

Brullo S., Minissale P., Spampinato G., 1995 Considerazioni fitogeografiche sulla flora della Sicilia. Ecologia Mediterranea, 21 (1/2): 99-117.

CABI 2017 - Bioscience databases index fungorum. http://www.indexfungorum.org/names/names.asp (visited on $07 / 15 / 2017$ ).

CAmpo G., Sidoti A., Perrotta G., 2015 - Indagine sullo stato fitosanitario delle popolazioni di Zelkova sicula. Regione Siciliana - Assessorato dell'Agricoltura, dello Sviluppo Rurale e della Pesca Mediterranea Dipartimento dello Sviluppo Rurale e Territoriale Servizio $7^{\circ}$ Forestale Servizio XVI - Ufficio Provinciale Azienda di Siracusa. http://www.zelkovazione.eu/sites/zelkovazione. eu/files/docs/Indagine $\% 20$ stato $\% 20$ fitosanitario $\% 20 Z \% 2$ 0sicula\%202015.pdf.

Ceccolini F., Barbagli F., Paggetti E., 2014 - Prima segnalazione di Acmaeoderella adspersula (Illiger, 1803) per l'isola di Stromboli (Coleoptera Buprestidae). - Il Naturalista Siciliano, S. IV, XXXVIII (1): 119-120.

Cloete M., Fourie P.H., Damm U., Crous P.W., Mostert L., 2011 - Fungi associated with die-back symptoms of apple and pear trees, a possible inoculum source of grapevine trunk disease pathogens. - Phytopathologia Mediterranea, 50 (Supplement): 176-190.

CONTARINI E., 2014 - Elenco faunistico commentato (checklist) dei Cerambicidi (Coleoptera Xylophytophaga) del Parco Naturale della Vena del Gesso Romagnola (Insecta Coleoptera Cerambycidae). - Quaderni Studi Nat. Romagna, 40: 39-65.

CRIST C.R., SHÖENEWEISS D.F., 1975 - The influence of controlled stresses on susceptibility of European white birch stems to attack by Botryosphaeria dothidea. Phytopathology, 65: 369-373.

Crous P.W., Slippers B., Wingfield M.J., Rheeder J., Marasas W.F.O., Philips A.J.L., Alves A., Burgess T., Barber P., Groenewald J.Z., 2006 - Phylogenetic lineages in the Botryosphaeriaceae. - Studies in Mycology, 55: 235-253. 
Curletti G., 1981 - Dati faunistici, biologici e sistematici nuovi od interessanti su alcuni buprestidi dell'Africa nord occidentale (Coleoptera, Buprestidae). - Rivista Piemontese di Storia Naturale, 2: 219-225.

Curletti G. 1994 - Buprestidi d'Italia. Catalogo Tassonomico, Sinonimico, Biologico, Geonemico. Monografie di Natura Bresciana, n. 19, 318 pp.

Damm U., Verkley G.J.M., Crous P.W., Fourie P.H., Haegi A., Riccioni L., 2008 - Novel Paraconiothyrium species on stone fruit trees and other woody hosts. Persoonia, 20: 9 -17.

Di Pasquale G., Garfì G., Quézel P. 1992 - Sur la présence d'un Zelkova nouveau en Sicile sud-orientale. Biocosme Mésogéen, 8-9: 401-409.

Dissanayake A.J., Phillips A.J.L., Li X.H., Hyde K.D., 2016 - Botryosphaeriaceae: Current status of genera and species. - Mycosphere, 7: 1001-1073.

Doll D.A., Rolshausen P.E., Pouzoulet J., Michailides T.J., 2015 - First report of Dothiorella iberica causing trunk and scaffold cankers of almond in California. Plant Disease, 99: 1185.

Domina G., Marino P., Spadaro V., Raimondo F.M., 2012 - Vascular flora evolution in the major Mediterranean islands. - Biodiversity Journal, 3 (4): 337-342.

Eskalen A., McDonald V.M., 2011 - Identification and distribution of Botryosphaeria spp. associated with Avocado branch cankers in California. - Proceedings VII World Avocado Congress 2011. Cairns, Australia. 5-9 September 2011.

FArR D.F., Rossman A.Y., 2016 - Fungal databases, systematic mycology and microbiology laboratory, ARS, USDA. (SMML database). https://nt.ars-grin.gov/ fungaldatabases (visited on 09/21/2016).

Fineschi S., Cozzolino S., Migliaccio M., Vendramin G.G., 2004 - Genetic variation of relic tree species: the case of Mediterranean Zelkova abelicea (Lam.) Boissier and Z. sicula Di Pasquale, Garfi and Quézel (Ulmaceae). - Forest Ecology and Management, 197: 273-278.

Frisullo S., Elshafie H.S., Mang S.M., 2015 - First report of two Phomopsis species on olive trees in Italy. Journal of Plant Pathology, 97 (2): 391-403.

García Morales M., Denno B.D., Miller D.R., Miller G.L., Ben-Dov Y., Hardy N.B., 2016 - ScaleNet: A literature-based model of scale insect biology and systematics. Database. doi: 10.1093/database/bav118. http://scalenet.info (visited on 08/03/2017).

GARFì G., BuORD S., 2012 - Relict species and the challenges for conservation: the emblematic case of Zelkova Sicula Di Pasquale, Garfi et Quézel and the efforts to save it from extinction. - Biodiversity Journal, 3 (4): 281-296.

Giardina G., Raimondo F.M., Spadaro V., 2007 - A catalogue of plants growing in Sicily. - Bocconea, 20: 5582.

Golzar H., Wang C., Tan, Y.P., Shivas, R.G., 2012 - First report of shoot blight of persimmon caused by Diaporthe neotheicola in Australia. - Australasian Plant Disease Notes, 7 (1): 115-117.

Granata G., Sidoti A., Tamburino V., 2002 - Funghi endofiti in arbusti di Zelkova sicula. - Atti del Convegno nazionale "L'endofitismo di funghi e batteri patogeni in piante arboree ed arbustive" Sassari - Tempio Pausania, 19-21 maggio 2002: 303-311.

GTC, 2017 - Global Trees Campaign. Securing the future of the world's threatened tree species. http://globaltrees .org/threatened-trees/trees/zelkova-sicula (visited on $05 / 30 / 2017$ ).
Jurc M., Csóka G., Hrašovec B., 2016 - Potentially important insect pests of Celtis australis in Slovenia, Croatia and Hungary. - Šumarski list, 11-12: 577-588.

Kaliterna J., Miličević T., Cvjetković B., 2012 Grapevine trunk diseases associated with fungi from the Diaporthaceae family in Croatian vineyards. - Arh Hig Rada Toksikol, 63: 471-479.

KOZLOWSKI G., GRATZFELD J., 2013 - Zelkova - an ancient tree. Global status and conservation action. - Natural History Museum Fribourg, Switzerland. http:// globaltrees.org/wp-content/uploads/2013/11/Zelkova ActionPlan_smallest.pdf (visited on 05/24/2017).

KuBAN V., Bílý S., 2013 - Fauna Europaea: Buprestidae. In: Alonso-Zarazaga MA (2013) Fauna Europaea: Coleoptera 1. Fauna Europaea Version 2.6.2., http://www.faunaeur.org (visited on 05/31/2017).

Ligoxigakis E.K., Papaionnnou I.A., Markakis E.A., TYPAS M.A., 2013 - First report of leaf spot of Phoenix theophrasti caused by Paraconiothyrium variabile in Greece. - Plant disease, 97 (9): 1250.

Longo S., CAMPo G., 2004 - Acmaeodera pilosellae (Coleoptera Buprestidae), xilofago di Zelkova sicula (Ulmacea) in Sicilia. - Atti XIX Congresso Nazionale Italiano di Entomologia, Catania 10-15 giugno, 2002, vol. II: 931-935.

LunA M., 2013 - I coleotteri buprestidi dell'appennino umbro (COLEOPTERA, BUPRESTIDAE). - Bollettino dell'Associazione Romana di Entomologia, 68 (1-4): 930.

Massa B., Sbordoni V., Vigna Taglianti A., 2011 - La Biogeografia della Sicilia: considerazioni conclusive sul XXXVII Congresso della Società Italiana di Biogeografia. - Biogeographia, 30: 685-694.

Mazzei P., Morel D., Panfili R., 2017 - Moths and Butterflies of Europe and North Africa. http://www.leps.it/indexjs.htm?SpeciesPages/SaturPavoe. htm (visited on 07/26/2017).

Mazzeo G., Nucifora S., Russo A., Suma P., Longo S., 2016 - An updated list of the scale insect (Hemiptera Coccomorpha) fauna of some Sicilian endemic plants. Redia, XCIX: 201-206.

Mifsud D., Barther H.B., 2005 - The jewel beetle (Coleoptera, Buprestidae) fauna of Malta - Remarks and Additions. - The Central Mediterranean Naturalist, 4 (2): 140.

Montmollin De B., Strahm W., 2005 - The top Mediterranean Island Plants: wild plants at the brink of extinction, and what is needed to save them. - IUCN/SCC (visited on 06/01/2017).

NGOBISA A.I.C.N., ABIDIN M.A.Z., Wong M.Y., Wan N.M., 2013 - Neofusicoccum ribis associated with leaf blight on rubber (Hevea brasiliensis) in Peninsular Malaysia. Plant Pathology Journal, 29: 10-16.

Phillips A.J.L., 2017 - Dothiorella sarmentorum. http://www.crem.fct.unl.pt/botryosphaeria_site/Botryosph aeria sarmentorum 2.htm (visited on 06/16/2017).

Phillips A.J.L., Alves A., Correia A., LuQue J., 2005 Two new species of Botryosphaeria with brown, 1-septate ascospores and Dothiorella anamorphs. - Micologia, 97(2): 513-529.

Pitt W., Huang R., Savocchia S., Steel C., 2008. - First Report of Dothiorella iberica (Botryosphaeria iberica) associated with Grapevine Decline in Australia. International Workshop on Grapevine Trunk Diseases (IWGTD). Italy: Firenze University Press, 2008.

PitTaWAY A.R., 2018 - Saturniidae of the Western Palaearctic (including Europe, North Africa, the Middle 
East, western Siberia and western Central Asia). http://tpittaway.tripod.com/silk/satlist.htm (visited on 01/29/2018).

Prado S., NAY B., Kunz C., 2015 - Paraconiothyrium variabile, an ascomycete endophyte, suppresses mycotoxin production in the plant pathogen Fusarium oxysporum. - Journal of Medical Mycology, 25 (2): 9697.

SAma G., 2013 - Fauna Europaea: Cerambycidae. In: Audisio P. (2013) Fauna Europaea: Coleoptera 1. Fauna Europaea Version 2.6.2., http://www.faunaeur.org (visited on $05 / 31 / 2017$ ).

Sama G., Buse J., Orbach E., Friedman A.L.L., Rittner O., Chikatunov V., 2010 - A new catalogue of the Cerambycidae (Coleoptera) of Israel with notes on their distribution and host plants. - Munis Entomology \& Zoology, 5 (1): 1-51.

Sidoti A., Granata G., 2005 - Diplodia sarmentorum $e$ Fusicoccum aesculi, agenti di cancri su Zelkova sicula. Micologia Italiana, 3, 44-48.

Sidoti, A., Campo, G., Perrotta, G., Pasotti, L., Raciti, E., CoRno, G., 2016 - Rapporto sullo Stato delle Foreste in Sicilia 2014. Avversità degli alberi e delle foreste. Palermo: Regione Siciliana. Assessorato Regionale dell'Agricoltura, dello Sviluppo Rurale e Territoriale e della Pesca mediterranea. Dipartimento Regionale dello Sviluppo Rurale e Territoriale. - Servizio 9 - Innovazione,
Ricerca, Divulgazione, Vivaismo Forestale e Difesa dei Boschi dalle Avversità. 37 pages. URL: http://pti. regione.sicilia.it/portal/pls/portal/docs/146263588.PDF (visited on 03/22/2017).

Slippers B., Crous P.W., Denman S., Coutinho T.A., WiNGFIELD B.D., 2004 - Combined multiple gene genealogies and phenotypic characters differentiate several species previously identified as Botryosphaeria dothidea. - Mycologia, 96: 83-101.

Smith D., Stanosz G., 2001 - Molecular and morphological differentiation of Botryosphaeria dothidea (anamorph Fusicoccum aesculi) from some other fungi with Fusicoccum anamorphs. - Mycologia, 93: 505-515.

Thomidis T., Exadaktylou E., Shuaifei C., 2013 Diaporthe neotheicola, a new threat for kiwifruit in Greece. - Crop protection, 47: 35-40.

Torta L., Burruano S., Sidoti A., Granata G., 2008 Latifoglie in Sicilia: un laboratorio di casi fitopatologici. - In: Ciancio O. (a cura di), Atti del Terzo Congresso Nazionale di Selvicoltura per il Miglioramento e la Conservazione dei Boschi Italiani, Accademia Italiana di Scienze Forestali, pp. 691-696.

Udayanga D., Castlebury L.A., Rossman A., Hyde K.D., 2014 - Species limits in Diaporthe: a molecular reassessment of $\mathrm{D}$. citri, D. cytosporella, D. foeniculina and $\mathrm{D}$. rudis. - Persoonia, 32: 83-101. 